\title{
Simultaneous estimation of income and price elasticities of export demand, scale economies and total factor productivity growth for Brazil
}

Citation for published version (APA):

Mutz, C., \& Ziesemer, T. H. W. (2005). Simultaneous estimation of income and price elasticities of export demand, scale economies and total factor productivity growth for Brazil. UNU-MERIT, Maastricht Economic and Social Research and Training Centre on Innovation and Technology. MERIT-Infonomics Research Memorandum Series No. 004 https://doi.org/10.26481/umamer.2005004

Document status and date:

Published: 01/01/2005

DOI:

10.26481/umamer.2005004

Document Version:

Publisher's PDF, also known as Version of record

Please check the document version of this publication:

- A submitted manuscript is the version of the article upon submission and before peer-review. There can be important differences between the submitted version and the official published version of record.

People interested in the research are advised to contact the author for the final version of the publication, or visit the DOI to the publisher's website.

- The final author version and the galley proof are versions of the publication after peer review.

- The final published version features the final layout of the paper including the volume, issue and page numbers.

Link to publication

\footnotetext{
General rights rights.

- You may freely distribute the URL identifying the publication in the public portal. please follow below link for the End User Agreement:

www.umlib.nl/taverne-license

Take down policy

If you believe that this document breaches copyright please contact us at:

repository@maastrichtuniversity.nl

providing details and we will investigate your claim.
}

Copyright and moral rights for the publications made accessible in the public portal are retained by the authors and/or other copyright owners and it is a condition of accessing publications that users recognise and abide by the legal requirements associated with these

- Users may download and print one copy of any publication from the public portal for the purpose of private study or research.

- You may not further distribute the material or use it for any profit-making activity or commercial gain

If the publication is distributed under the terms of Article 25fa of the Dutch Copyright Act, indicated by the "Taverne" license above, 
MERIT-Infonomics Research Memorandum series

Simultaneous Estimation of Income and Price Elasticities of Export Demand, Scale Economies and Total Factor Productivity Growth for Brazil

\section{Christine Mutz \& Thomas Ziesemer}

2005-004

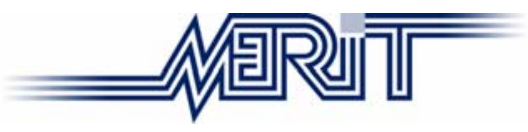

MERIT - Maastricht Economic Research

Institute on Innovation and Technology

PO Box 616

6200 MD Maastricht

The Netherlands

$\mathrm{T}:+31433883875$

F: +31433884905

http://www.merit.unimaas.nl

e-mail:secr-merit@merit.unimaas.nl

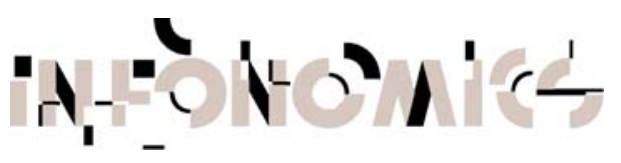

International Institute of Infonomics

c/o Maastricht University

PO Box 616

6200 MD Maastricht

The Netherlands

T: +31 433883875

F: +31 453884905

http://www.infonomics.nl e-mail: secr@infonomics.nl 


\title{
Simultaneous Estimation of Income and Price Elasticities of Export Demand, Scale Economies and Total Factor Productivity Growth for Brazil
}

\author{
Christine Mutz, Leipzig Graduate School of Management \\ Thomas Ziesemer, Maastricht University, Department of Economics and MERIT, \\ P.O.Box 616, NL 6200 MD Maastricht. ${ }^{1}$ T.Ziesemer@algec.unimaas.nl \\ February 2005
}

\begin{abstract}
This paper focuses on a model in which low (high) export demand elasticities and the fact that developing countries are importers of capital goods help explaining the slow (high) growth of these countries. The question arises whether export demand elasticities are low or high. For answering this question, export demand elasticities for the case of Brazil are estimated using a growth model. As a by-product of estimating the model, we obtain estimates for total-factor productivity growth and for scale economies. Based on the results from estimation we calculate steady-state growth rates, engine and handmaiden effects of growth as well as dynamic steady-state gains from trade. The model and the results are discussed in regard to several strands of literature.
\end{abstract}

Keywords: Development, international linkages, open economy growth models, timeseries.

JEL code: $\mathrm{O} 11, \mathrm{O} 19, \mathrm{O} 41, \mathrm{~F} 43, \mathrm{C} 51$ 


\section{Introduction}

Income and price elasticities of export demand are important for several reasons. When real devaluations occur, the value of exports increases (decreases) if export demand is price-(in)elastic. Therefore, more (less) imports can be bought from abroad. If imports are investment goods, this increases (decreases) investment. In particular, if technical progress yields lower terms of trade, this transmits more or less strongly into growth rates of exports and investment; and if booming exports drive up the terms of trade, it depends on price elasticities how strongly this boom is curtailing itself by boosting the terms of trade. Income elasticities of export demand determine how strongly growth abroad is translated into growth in exports. Again, if investment goods are paid for by these exports, the income elasticities of export demand have an impact on growth and on dynamic gains from trade.

In this paper, we estimate income and price elasticities of export demand from a slightly modified version of a two-gap growth model with imported inputs, introduced by Bardhan and Lewis (1970). In doing so, we hope to contribute to several strands of literature. First, the literature on exports and growth has benefited much from the insight that imported inputs paid by exports are the major mechanism in the relation between exports and growth in the short run (see Khan and Knight, 1988) and in the long run (see Esfahani, 1991). Similarly, Levine and Renelt (1992), and Wacziarg (2001) found that the major channel for trade and growth is investment. In line with that idea, recent timeseries literature found that the causality going from exports to output growth is stronger than that going vice versa (see Riezman et al., 1996; Islam, 1998; Asafu-Adjaye and Chakraborty, 1999; Krishna et al., 2003). ${ }^{2}$ Riezman et al. (1996) pointed out that this 
'may serve as a guide to theorists who are currently working to develop better theories of economic growth'. We would like to recall that such a theory already exists since long: in the widely ignored model by Bardhan and Lewis (1970), exports are a second driving force for growth besides technical change because investment goods are imported. We use that model but go one step further: we estimate a full-fledged growth model rather than extended production functions or ad hoc specifications in order to get estimates of the export elasticities, total factor productivity growth and scale economies.

Second, growth and dynamic gains from trade are closely related since the question is whether trade increases the growth rate of the economy (see Lewer and van den Berg, 2003, for a recent survey). The larger the income elasticity of export demand the larger the growth rate of the economy in the model used below. Our estimates allow calculating the steady-state part of the dynamic gains from trade conditional on assumptions about future employment growth.

Third, the literature on balance of payments constrained growth is closely linked to that of two-gap models. In these models, the standard approach is to solve the balance of payments for the relative growth rate of the country in question and the world and to assume that terms of trade are constant or have no impact (see Bertola et al., 2002, for a recent contribution). The terms of trade have been made endogenous by Fagerberg (1988), who assumes that they equal relative unit labour costs, which in turn are exogenous though. In Verspagen (1993, Chap.7) relative unit labour costs depend on a Verdoorn effect, thus the terms of trade are endogenous. However, in his model, demand has no direct effect on the terms of trade as in the Bardhan and Lewis model, on which we base our estimates. In short, the demand side is added to that literature and we 
estimate its parameters in order to determine the effects of both, technological change and demand, on the terms of trade.

Fourth, there is the literature concerning the effects of devaluations or concerning the explanation of terms of trade movements. Here, the income and price elasticities of export demand are estimated from export demand functions (Riedel and Athukorala, 1995; Mody and Yilmaz, 1997; Senhadji and Montenegro, 1998), from partial equilibrium models of export demand and supply (Muscatelli, 1995; Madsen, 1999; Catão and Falcetti, 1999) and from demand side parts of a general equilibrium model (see Reinhart, 1995). In contrast to those approaches relying on partial equilibrium models, we use a growth model for our estimates.

Fifth, the slightly modified Bardhan and Lewis model serves as a theoretical foundation of the thoughts of Prebisch and Singer (see Ziesemer, 1995). Our estimates are the empirical complement to that theory, containing both parts of the history of economic thought, namely the engine and the handmaiden part of growth. As a byproduct of our procedure, we also get estimates of total-factor-productivity growth and of scale economies for Brazil, which is the country for which we carry out the estimation.

The paper is set up as follows. In section 2 we present the model and compare it to the neoclassical growth model. Section 3 describes the data. Estimates of the growth model using the general method of moments estimator (GMM) are presented in section 4. In section 5, we use the estimated results to calculate steady-state growth rates, engine and handmaiden effects, and dynamic steady-state gains from trade. Section 6 relates the results to the aforementioned branches of the literature. 


\section{The Model}

The question dealt with in this section is whether imports of capital goods and low (high) export demand elasticities could account for slow (fast) growth in comparison with the Solow (1956) growth model. The model assumes flexible wages and exogenous employment. A Cobb-Douglas production function with exogenous technical progress is used:

$$
Y=e^{b t} A K^{\beta} L^{\alpha} U, 0<\alpha, \beta<1, \alpha+\beta \geq(\leq) 1
$$

$Y$ denotes output, $K$ capital, $L$ labour, $b$ the rate of technological progress, 'A' is a time independent constant, $\mathrm{U}$ a stochastic term and $\alpha$ and $\beta$ the elasticity of production of labour and capital. We allow for increasing, decreasing and constant returns to scale. Labour is assumed to grow at rate $\varepsilon$, which is determined exogenously:

$$
L(t)=L(0) e^{\varepsilon t}, \hat{L}=\varepsilon
$$

A "hat" over a variable indicates a growth rate. The fact that they are importers of capital goods seems to be a fundamental problem of developing countries. Importing less luxury consumption goods may be helpful but cannot be a solution by itself. Therefore, it is assumed that no luxury items are imported. Problems referring to the terms of trade or growth may occur despite the absence of imports other than capital goods. Fundamental obstacles for developing economies are rather the importation of capital goods as well as limited export demand. By assumption, capital goods invested in developing countries must be imported: 


$$
M=\dot{K}
$$

A "dot" over a variable denotes its derivative with respect to time, and $M$ represents imports. Capital goods are the only imports - another simplification besides the absence of foreign debt - and have to be paid for by exports. This requirement stems from the trade-balance equilibrium. Investments are, therefore, limited by exports, denoted by $X$, which are expressed in terms of the imported capital goods:

$$
\hat{K}=\frac{\dot{K}}{K}=p \frac{X}{K}-\delta, \hat{\hat{K}}=\hat{p}+\hat{X}-\hat{K}
$$

$p$ represents the terms of trade, defined as the price of domestic goods in terms of imported capital goods. Investments need to be paid for by domestic savings measured in terms of imported capital goods. The savings rate $s$ is assumed to be a constant proportion of output in this theoretical part and depreciation is $\delta K$ :

$$
\hat{K}=\frac{\dot{K}}{K}=s p \frac{Y}{K}-\delta, \quad \hat{\hat{K}}=\hat{p}+\hat{Y}-\hat{K}
$$

Investments are limited by exports. Exports in turn are assumed to depend on the trade partners' income, $Z$, and on the terms of trade. For the sake of simplicity, a log-linear export function with a constant $\mathrm{B}^{3}$ and a stochastic term $V$ is used:

$$
X=B Z^{\rho} p^{\eta} V, \rho>0, \eta<0
$$


$\rho$ denotes the income elasticity and $\eta$ represents the (negative) price elasticity of export demand. Together, these six equations explain the six variables $Y, L, M, p, K$, and $X$.

Inserting the functions for exports and output, (6) and (1), into the export and saving constraint for investment, (4) and (5), respectively, writing the depreciation rate on the left hand side and taking natural logs, denoted $\ln$, yields:

$$
\begin{gathered}
\ln (\hat{K}+\delta)=\ln B+\rho \ln Z+(1+\eta) \ln p+\ln V-\ln K \\
\ln (\hat{K}+\delta)=\ln p+b t+\ln A+(\beta-1) \ln K+\alpha \ln L+\ln U
\end{gathered}
$$

Uncertainty is kept as inessential and simple as possible here because we are not interested in any uncertainty aspect per se but rather need this aspect only to relate it to econometric models. Basically, the assumption is that firms know $L$ and $K$ (from the previous period) with certainty and produce after $U$ has become known. Households then decide to save a fraction $s$ of their income $Y$ and this determines gross investment. When the $\mathrm{V}$-term in the export function is known, $p$ can adjust to determine external equilibrium. All rigidities and the implied consequences for the future are assumed to be absent for the sake of simplicity. In particular, the irreversibility of capital is assumed to be irrelevant. In a more sophisticated investment theory this is only justified if the optimal capital stock never decreases by more than depreciation.

In our model, the output per worker in units of domestic goods is considered a rough indicator of welfare. The driving forces behind the expected value (denoted by $E$ ) of the latter are the rate of technical progress and the growth rate of the capital-labour ratio, which is denoted by $k$ (with $E(\ln U)=0)$ :

$$
\hat{y}=b+\beta \hat{k}+(\alpha+\beta-1) \hat{L}
$$


The last term corrects for scale economies. Since the rate of technical progress is given, the remaining question is whether a low income elasticity of export demand hinders rapid growth of the capital-labour ratio by restricting the importation of capital goods. The growth rates for the long-term equilibrium growth path are of crucial interest in this respect. Solving equations (4') and (5') for the natural log of the terms of trade and the left hand side variable yields:

$$
\begin{aligned}
& \ln (\hat{K}+\delta)=\frac{-\ln B}{\eta}+\ln A \frac{(\eta+1)}{\eta}+\frac{\eta+1}{\eta} \ln s+\frac{b(\eta+1)}{\eta} t+\frac{\beta \eta+\beta-\eta}{\eta} \ln K \\
& +\frac{\alpha(\eta+1)}{\eta} \ln L+\frac{-\rho}{\eta} \ln Z+\frac{\eta+1}{\eta} \ln U-\frac{1}{\eta} \ln V \\
& \ln p=\frac{\ln A-\ln B}{\eta}++\frac{1}{\eta} \ln s+\frac{b}{\eta} t+\frac{\beta}{\eta} \ln K+\frac{\alpha}{\eta} \ln L-\frac{\rho}{\eta} \ln Z+\frac{1}{\eta}(\ln U-\ln V)
\end{aligned}
$$

The expected value (setting $\ln U=\ln V=0$ henceforth) of equation (8) is a differential equation of $K$ with negative slope. $\mathrm{K}$ has an impact on equation (9) but $\ln p$ has none on (8).

The next step is to take the derivative with respect to time of both equations, set both sides equal to zero and assume a constant savings ratio in the steady state. Then the steady-state growth rate can be written as follows:

$$
\hat{k}=\frac{\rho \hat{Z}-\varepsilon-(1+\eta)[(\alpha+\beta-1) \varepsilon+b]}{-\eta(1-\beta)+\beta}
$$


Inserting this solution into the equation determining the change in the terms of trade and into equation (7) yields the following solutions for the terms of trade and income per capita, respectively:

$$
\begin{gathered}
\hat{p}=\frac{(1-\beta)(\rho \hat{Z}-\varepsilon)-(\alpha+\beta-1) \varepsilon-b}{-\eta(1-\beta)+\beta} \\
\hat{y}=\frac{\beta(\rho \hat{Z}-\varepsilon)-\eta((\alpha+\beta-1) \varepsilon+b)}{-\eta(1-\beta)+\beta}
\end{gathered}
$$

The numerators of equations (10) to (12) consist of three terms, the first of which reflects the "engine of growth" part from the export demand function: the growth rate of world income multiplied by the income elasticity of export demand minus the population growth rate. The product of trade partners' income and income elasticity is the driving force on the demand side. Hence, this part represents the ideas of Prebisch. The last part, on the other hand, captures the handmaiden part (see Kravis 1970). This term supports the view that technical progress leads to an increase in exports via decreased prices if exports are price elastic. Consequently, the causality of this last effects runs from growth to exports, opposite to what the engine of growth supporters propose. Our model contains both parts. Note, however, that the handmaiden part drops out if a country has no technical progress. The third part is only relevant in case of non-constant returns to scale. With increasing returns to scale we have an additional cost reduction which drops out only if $(\alpha+\beta=1)$ in (10)-(12). 
The direct effect of technical progress and returns to scale is to decrease production costs and to reduce the terms of trade as can be read off equation (11). The question then arises whether this will cause exports and investments to rise or fall. Assuming exports are price-elastic, there will be an increase in exports and investments as well as in the capital-labour ratio in equation (10). If exports are price-inelastic, however, technical progress has a negative impact on the growth rate of the capital-labour ratio. Considering the growth rate of income per capita, it is obvious that technical progress has not only a direct but also an indirect effect on this variable. The latter effect is due to changes in the capital-labour ratio induced by technical progress. The direct effect outweighs the indirect one so that technical progress always has a positive impact on real wages.

Summing up, technical progress and returns to scale have a negative impact on the terms of trade while they influence per capita income positively. The higher the income elasticity the higher the growth of export demand for any growth rate of world income and the higher the growth rate of capital imports in equation (10). The latter aspect causes income in equation (12) to grow at a higher rate and the growth rate of the terms of trade is driven up as well. A higher growth rate of income in the trade partners' countries will lead to an increase in exports. Yet, the critical point is whether the change in income multiplied by the income elasticity, $\rho \hat{Z}$, exceeds the population growth rate $\varepsilon$. This difference governs the growth rate of the capital-labour ratio in equation (10) in case of constant returns to scale. If the income elasticity of export demand is low and the population growth rate is high, the effect on the growth rates concerning the terms of trade, the capital-labour ratio, and income per capita will be negative. 
In conclusion, the terms of trade will fall on condition that the rate of technical progress and scale economies is not exceeded by a large difference between the export growth rate and the population growth rate in equation (12). The growth rates of the capital-labour ratio and income per capita may be negative because of low income and price elasticities. With respect to income elasticity and trade partners' income growth, the terms of trade are an indicator of economic development because they boost both, per capita income and the terms of trade.

\section{Comparison with the Results of the Solow Growth Model}

The Prebisch-Singer thesis poses the task of presenting trade conditions which result in a slower growth rate for the main economic indicators of welfare than in the Solow model. Considering a Solow model with a constant-returns-to-scale production function like equation (1), the capital-labour ratio and per capita income grow at the same rate, $b /(1-\beta)$. In the model examined above, this result can be obtained by means of taking into account two special cases. First, equation (12) can be written in the form:

$$
\hat{y}=\frac{b}{(1-\beta)}\left\{1-\frac{\beta}{[\eta(1-\beta)]}\right\}+\frac{(\rho \hat{Z}-\varepsilon) \beta}{[-\eta(1-\beta)+\beta]},
$$

For any value of $\rho \hat{Z}$, it holds that $\hat{y}=b /(1-\beta)$ assuming that $\eta$ approaches minus infinity. This is the small country case in neoclassical models. Second, it can be shown that $\hat{y}=b /(1-\beta)$ and $\hat{p}=0$, both if $\rho \hat{Z}-\varepsilon=b /(1-\beta)$, just like a closed economy in the Solow model. Then, the engine of growth, $\rho \hat{Z}-\varepsilon$, has the same effect as the handmaiden part, $b /(1-\beta)$, and therefore, the growth rate coincides with that of the Solow model. 
Figure 1 presents $\hat{y}$ as a function of $\rho$ for different values of $\eta$ under the assumption made to emphasize the role of the income elasticity - that $\hat{Z}=\varepsilon+b /(1-\beta)$ and of constant returns for both models because the Solow model is normally presented in this way. The vertical intercept increases with the price elasticity of exports. The slope, on the other hand, is less steep the more price-elastic exports are.

\section{FIGURE 1 OVER HERE}

Due to equation $\left(12^{\prime}\right)$, there is one straight line for each value of $\eta$, being equal to $b /(1-\beta)$ at $\rho=1$. The horizontal line represents the small country case with the price elasticity being equal to minus infinity. It shows that in this case exports constitute no constraint to growth, a conclusion that is in line with traditional neoclassical thinking. Figure 1 reveals that the capital importing economy grows at a lower rate than in Solow's model if the income elasticity is lower than one. For income elasticities greater than one, the economy grows faster than predicted by the Solow model. These conclusions do not hold for a price elasticity of minus infinity, since this is the small country case.

In view of the interplay between the growth rate of the terms of trade and the income elasticity of export demand, a similar graph is drawn in figure 2. The less price-elastic exports the steeper the slope and the more negative the vertical intercept. For income elasticities smaller than one, the growth rate of the terms of trade fall and real wages grow at a lower rate than in the Solow model. There is, thus, a close relationship between the latter two variables. The driving force behind both of them is the income elasticity of export demand. The effect of the latter is reinforced by a lower price elasticity of export 
demand. The obvious corollary is that of a high price elasticity weakening the impact of the income elasticity of export demand on the developments of real income and the terms

of trade. As in the previous graph, the relationship is drawn for $\hat{Z}=\varepsilon+b /(1-\beta)$ and alternative values for the price elasticity. To summarize, the price and income elasticities of export demand are crucial determinants for a developing country's growth prospects.

\section{FIGURE 2 OVER HERE}

In this model the importation of capital goods and low (high) elasticities of export demand contribute to explaining the slow (fast) growth of developing countries. The question now arises whether these price and income elasticities are indeed low. That issue is taken up in the following sections.

Again, we would like to point out the simplifying assumptions we have made: absence of domestic capital goods, imported consumption goods, foreign debt, and unbalanced trade. None of these assumptions holds true for Brazil as can easily be seen by examining the World Development Indicators. ${ }^{4}$ Whether or not the abstraction is too strong will be revealed by the econometric work. After all, the widely used Solow growth model is a special case of our model. The former ignores imported inputs and the exports used to pay for them, whereas we ignore that a large part of capital goods is produced domestically. Furthermore, past empirical studies estimating export demand income and price elasticities use a similar export demand function but do not make use of a growth model for the supply side as we do. Integrating all of these neglected aspects in a fullyfledged model would require the estimation of many more parameters with a small 
number of observations. Therefore, it is not necessarily a drawback to use this simple model. In a model including domestic capital goods, these would have to grow at a rate that is proportional to that of foreign capital goods in order to avoid running too much into decreasing returns to the accumulation of one of them only. Absence of debt is dealt with by using the investment/GDP ratio rather than the savings ratio. Khan and Knight (1988), and Esfahani (1991) also assume all imports to be inputs. It can only be hoped for that the other aspects would merely change the intercept of the regressions below. This is a matter left for future work.

The equations estimated below are (8) and (9). Note that these equations hold for both, the steady state and the transition path. We want to estimate the equations as a simultaneous system. Once one equation is estimated, it is obvious that all parameters can be identified. Therefore, we have one constraint per regressor except for the intercept and the world income variable, which has the same coefficient in both equations.

\section{The data}

We decided to carry out the empirical estimation for Brazil because all data are available. In order to estimate the equations, time series for the savings or investment/GDP ratio, capital, trade partners' income and employment are required. The data for gross fixed capital formation as percentage of (GDP minus depreciation) are taken from the World Development Indicators 2004 and represent investment. We make use of this figure instead of the savings ratio in order to account for that part of investment financed by foreign debt, which is ignored by our model. The data for capital are constructed by 
cumulating Gross Fixed Capital Formation after subtraction of the data for depreciation, starting from an initial value determined according to the formula ${ }^{5}$

$$
K_{0}=\frac{I_{1}}{\left(\hat{K}_{1}+\delta\right)}
$$

Depreciation is assumed to be $3.7 \%$ of capital for all periods because this is the average value of available figures in earlier national accounts data. For $I_{1}$ we use gross fixed capital formation as of 1970 . The initial growth rate of the capital stock in the above formula is assumed to be .1, which corresponds to the order of magnitude of the growth rates of GDP and employment in those years. With the capital stock obtained in this way we can determine growth rates as log differences and add the rate of depreciation to get the dependent variable of equation (8). The employment data are taken from the ILO website. The time series starts in 1972 but values for the years 1974, 1975, 1980, 1991, 1994, 2000, 2001 are missing. We do not try to interpolate them because in an earlier attempt we found that different ways of doing so removed the unit root processes in the time series. Trade partners' income is taken to be world income since Brazil is trading with all the countries in the world. The terms of trade are calculated as 'Exports as capacity to import' divided by 'exports of goods and services', both in terms of constant local currency units. Data are available in the appendix to the working paper version.

\section{Econometric methods and estimation results for the system of equations}

Econometric methods have been developed traditionally either for stationary variables and more recently for variables being integrated of order one, I(1). Before 
discussing the methods we check whether the time series follow unit root processes and determine the order of integration of the variables. Testing for unit roots suffers from the fact that these tests have been designed for a large number of observations whereas we deal with only a few observations. Hence, the tests have low explanatory power. For world income the ADF test does not reject the unit root hypothesis. All other variables do not follow unit root processes. Consequently, we use equations (8) and (9) with only one modification: we replace $\ln Z$ by $d(\ln Z)^{*} t$, which can be based on rewriting the export function as $X=e^{\rho d \ln Z^{* t}} p^{\eta}=Z^{\rho} p^{\eta}$. The latter version of the variable does not have a unit root according to the standard ADF test. So we can use equations (8) and (9) in their current form.

The system has three important properties. First, there are constraints on the coefficients, generating a non-linear problem of estimation. Second, both equations of the system contain the random terms from the production function and the export function and therefore the residuals of the two equations will not be independent. These two properties together suggest using the seemingly unrelated regression (SUR) method. Third, equation (8) is a differential equation. Residuals have a positive impact on the dependent variable, enhancing the capital variable on the right hand side in the next period. As this is a stock variable, the effect is permanent. In other words, the residuals have an impact on all future variables of capital and the regressor in the first equation is not exogenous although it is predetermined (see Davidson and Mackinnon 2004, chapter 3.2). As this would bias the estimates, we use the generalized method of moments (GMM-HAC with heteroscedasticity and autocorrelation correction of the coefficient standard deviations) including all regressors and lagged variables of capital as 
instruments. We present the GMM estimate in the first column of Table 1 (see also unpublished Appendix to the working paper version).

\section{TABLE 1 OVER HERE}

The over-identifying constraints for the additional instruments are significant since the product of the J-statistic and the number of observations is low enough. As there are four constraints in the two equations, we have at least four degrees of freedom. However, the number of lagged instruments has to be added (see Greene 2003, p.548/9). The income elasticity of export demand (0.19) is at the lower end of the range of earlier estimates and the price elasticity (-1.86) is larger in absolute terms than in previous studies (see Table 2 for a comparison).

\section{TABLE 2 OVER HERE}

The time trend representing technical progress is significant and has the expected sign. The rate of total factor productivity growth is about $2 \%$. Given the elasticity of production of labour of about .5, the labour augmenting rate of technical change is $4 \%$. This figure is a bit larger than in estimations assuming constant returns to scale. However, the sum of the elasticities of production is $.81<1$ and indicates decreasing returns to scale at a measure of .19. If we arbitrarily (and therefore not shown) drop the time variable, we get increasing returns to scale. As shown above, the Solow growth model is a special case of our model in which the price elasticity should equal minus infinity. This would require $c(2)=1$. Given the high significance of the value around 0.5 it is clear that the alternative (to our model) hypothesis of the Solow model will be rejected by an F-test. The formulas for the identification of the parameters of the production function indicate that the estimated coefficients have to be in narrowly defined ranges in 
order to get reasonable parameter values for the model. In this sense the estimate for the system is quite encouraging. The only trouble here comes from the serial correlation as indicated by a very low DW statistic ${ }^{6}$. The standard procedure is to add lagged dependent variables. The result of adding one lag in each equation is shown in the second equation in Table1. The income elasticity of export demand is slightly higher now. The price elasticity has doubled. The growth rate of total factor productivity is now much smaller at about $1 \%$. The decreasing returns measure is still .19 because the elasticity of production of capital is enhanced at the cost of that of labour. There still is autocorrelation in the first equation (also according to a Breusch-Godfrey test, which is not shown). In order to correct for this autocorrelation we save the residuals from the first equation and add their lagged values to the regression (also as instruments). ${ }^{7}$ The result is the third regression in Table 1. The total factor productivity growth rate has fallen again to one third of a percent and has become insignificant again. We now get almost exactly constant returns to scale. The export elasticities are a bit lower than in the previous regression but still higher than in the first. Due to this last step of including lagged values of the residuals five observations are lost. Trying to carry out another Breusch-Godfrey test including one more lag leaves us with too little observations to do so.

\section{Steady state growth rates, engine and handmaiden effect, and dynamic gains}

\section{from trade}

We have estimated the model for its non-steady-state version. For long-run predictions, the theory gives us the steady-state formulas for growth rates of expected values. Note that in the estimated parts of the model, no use was made of the assumption of perfect 
competition, which is not in accordance with increasing returns to scale. In this section, we calculate the steady-state growth rates for equations (10)-(12) numerically so as to specify the long-run predictions of the estimated models. We define and calculate the engine and handmaiden effect in order to compare them to each other and in order to compare them to the effect export growth rates have on GDP per capita growth rates in the survey of Lewer and van den Berg (2003). Finally, we calculate the corresponding growth rates of the Solow growth model as well as define the difference between the predicted growth of our model and that of the corresponding Solow model as the dynamic gains from trade.

\section{TABLE 3 OVER HERE}

In Table 3, we report the steady-state results for the growth rates of $k, p$ and $y$. Additionally, the following effects - extracted from equations (10)-(12) - are presented: $g(m, s)$ indicates the engine (handmaiden, scale) effect, obtained as the derivative of the formula for the growth rate of $y$ with respect to the growth rate $d \ln Z(b, d \ln L)$.

$$
g=\frac{\beta \rho}{\beta(\eta+1)-\eta}, m=\frac{-\eta}{\beta(\eta+1)-\eta}, s=\frac{-\eta(\alpha+\beta-1)}{\beta(\eta+1)-\eta}
$$

The scale effect is the effect of $d \ln L$ only to the extent that it would drop out if there were constant returns to scale. Next, $x$ represents the corresponding growth rate of the Solow model under the assumption that its parameters are identical to those of our estimates. Finally, the difference in the growth rates of our model, $d$ lny, and the corresponding Solow model, denoted as $t$, is defined as the dynamic steady-state gains from trade. The parameter values are those from the last equation of Table 1.

$x=\frac{b+(\alpha+\beta-1) \varepsilon}{\beta \eta+\beta-\eta}, t=d \ln y-x$ 
All calculations are done under the assumption that world income will continue to grow at $2.6 \%$. Finally, we need an assumption for the growth rate of employment. This rate was anything but constant in the past as can be seen from the following regression:

$$
\begin{aligned}
\ln L & =9.71+.06 t-.00057 t^{2} \\
& (212)(17.2)(-9.16) \quad \text { adj. } R^{2}=.993
\end{aligned}
$$

A plot of the regression result and its time derivative representing the growth of employment appears in Figure 4. The result indicates that the growth rate of labour drops to zero at time $t>50$, which is after the year 2010 .

\section{FIGURE 4 OVER HERE}

The results are as follows. The steady-state growth rates of capital and income per capita are positive only if employment growth is sufficiently small, at about $1 \%$. This is due to the low income elasticity of export demand and little technical progress. The presence of the scale effect is too weak to outweigh these two effects. The positive growth rates of the past are therefore generated by the transitional growth of capital accumulation. The terms of trade are falling - as the data reveals for the past - because the growth of the supply force, employment plus technical change, is larger than that of the demand force, world income multiplied by the income elasticity. The terms of trade are not falling, only in a steady state where population growth occurs at a rate of roughly $.1 \%$. The handmaiden effect, $m=1.27$, is larger than the engine effect, $g=.024$, and the scale effect, $s=-.0077$, again because the income elasticity of export demand and the measure of decreasing returns are very small. The handmaiden effect multiplied by the rate of technical change is still larger than the engine effect multiplied by the difference of world income growth rate and population growth rate. With lower population growth, 
this effect gets larger (see third but last line in Table 3) and the scale effect vanishes (last line of Table 3$)$.

The closed economy growth rate is driven by decreasing returns to scale, employment growth and technical change. The lower future employment growth the higher will be the hypothetical autarkic growth rate. The growth rate of our model and the autarkic ones are higher if employment growth is lower. The steady-state part of the dynamic gains from trade becomes positive before employment growth is as low as .001 which will be the case around the year 2012 according to Figure 4, with period 1 representing the year 1960. Lewer and van den Berg (2003) illustrate that dynamic gains from trade are large when export growth rates are high in the transition after taking policy measures. Therefore, static gains from trade and the ones during transition may be larger than those in the steady state even if the latter are negative, which need not be the case if population growth falls far enough.

\section{Conclusion}

From the perspective of the exports and growth literature, we add economic causality - in the sense of estimating a growth model that contains an economic mechanism turning world income growth through exports via imported inputs into growth - to the econometric Granger causality of the literature. The model shows that the size of the income elasticity is crucial. According to our estimates, it is fairly low for Brazil and therefore the engine of growth effect is low as well.

From the perspective of the literature on balance of payments constrained growth, we have added the element of demand side effects on flexible terms of trade. It is obvious 
that price movements matter for the value of exports: If the income elasticity is larger than unity, growth will be enhanced through exports. If the income elasticity is lower than unity, growth will be reduced unless the price elasticity is minus infinity. A low income elasticity in connection with some technical progress leads to falling terms of trade in the steady state, giving rise to a relaxation of the balance of payments constraint. In the opposite cases, endogenous terms of trade lead to a tightening of the balance of payments constraint. This effect should be taken into account. Our empirical study shows that a low income elasticity dilutes the engine effect, the terms of trade will continue to fall in the steady state and therefore the balance of payments constraint is relaxed. Due to a relatively high price elasticity of about minus four growth is not hampered.

Next, there is the literature on devaluations, emphasizing the effects of devaluations or explaining the terms of trade movements. Keeping in mind that nominal devaluations have real effects (Bahmani-Oskooee and Miteza, 2002) our finding of a price elasticity of about minus four implies higher growth following devaluations.

Finally, from the perspective of the Prebisch-Singer thesis, the results clearly demonstrate that income and price elasticities of export demand may be important for the growth of Brazil in the period we have considered. In particular, if technical progress is low, a high world income growth multiplied by the income elasticity of export demand has to outweigh the population growth multiplied by the decreasing returns measure. Without the engine effect, i.e. in a closed economy, there would be no long-run per capita income growth if there are constant returns to scale and no technical change. Under increasing (decreasing) returns the impact of employment growth is less (more) negative than under constant returns. If population growth is low enough, the model allows for 
positive per capita income growth through imported capital goods, positive dynamic gains from trade and increasing terms of trade. However, if employment growth is large, negative rates are also possible. According to our estimates, the income elasticity is small, thus hampering growth and driving down the terms of trade in line with the Prebisch's expectations. However, the effect is only weak due to a relatively high price elasticity of export demand, which translates the falling terms of trade and therefore the effect of technical progress into a high export demand as expected by Kravis. Both arguments interact and are quantitatively relevant. According to our model, neither of the two can be dismissed because technical change matters on the supply side and exports are important determinants on the demand side.

The steady-state part of dynamic gains from international trade is dependent on the magnitude of employment growth: high employment growth yields negative dynamic gains from trade in the steady state whereas low employment growth brings about positive gains from trade. If employment continues to grow at such a high rate as in the past, dynamic gains from trade will be negative in the future. But the trend in employment data points to the opposite direction. As population growth approaches zero, positive dynamic gains from trade are generated by world income growth, which translates into higher demand for exports, and technical change multiplied by the price elasticity. 


\section{References}

Asafu-Adjaye, J. and D. Chakraborty. 1999. Export-led Growth and Import compression: Further time Series Evidence from LDCs, Australian Economic Papers, June, pp. 164174.

Bahmani-Oskooee, M. and M. Miteza. 2002. Do nominal devaluations lead to real devaluations in LDCs? Economics Letters, 74, pp. 385-391.

Bairam, E.I. 1993. Income Elasticities of Exports and Imports: A Re-Examination of the Empirical Evidence, Applied Economics, 25, pp. 71-74.

Bardhan, P.K. and S. Lewis. 1970. Models of Growth with Imported Inputs, Economica, November, p. 373.

Bértola, L., H.Higachi and G. Porcile. 2002. Balance-of-payments-constrained growth in Brazil: a test of Thirlwall's Law, 1890-1973, Journal of Post-Keynesian Economics, 25(1), Fall, pp. 123-140.

Catão, L. and E. Falcetti. 1999. Determinants of Argentina's External Trade, International Monetary Fund Working Papers, WO/99/121.

Davidson, R. and J.G. MacKinnon (2004). Econometric Theory and Methods. Oxford University Press. Auckland et al.

Dawson, P.J. and L.J. Hubbard. 2004. Exports and economic growth in Central and East European countries during transition, Applied Economics, 36, 1819-1824.

Dritsakis, N. 2004. Exports, investments and economic development of pre-accession countries of the European Union: an empirical investigation of Bulgaria and Romania, Applied Economics, 36, 1831-1838.

Esfahani, H.S. 1991. Exports, imports, and economic growth in semi-industrialized countries, Journal of Development Economics, 35, pp. 93-116.

Fagerberg, J. 1988. International Competitiveness, Economic Journal, 98, June, pp. 355374.

Fullerton, T.M., Jr, W.C. Sawyer and R.L. Sprinkle. 1999. Latin American Trade Elasticities, Journal of Economics and Finance, Vol. 23, no. 2, pp. 143-156.

Houthakker, H.S. and S.P. Magee. 1969. Income and Price Elasticities in World Trade, The Review of Economics and Statistics, Vol. LI, no. 2, pp. 111-125.

Islam, M.N. 1998. Export Expansion and Economic Growth: Testing for Cointegration and Causality, Applied Economics, 30, pp. 415-425. 
Khan, M.S. and M.D. Knight. 1988. Import Compression and Export Performance in Developing Countries, Review of Economics and Statistics, Vol. 70(2), pp. 315-321.

Kravis, I.B. 1970. Trade as a Handmaiden of Growth, Economic Journal, December, pp. 850-872.

Krishna, K., A.Ozyildirim and N.R. Swanson. 2003. Trade, investment and growth: nexus, analysis and prognosis, Journal of Development Economics, 70, pp. 479-499.

Lewer, J.J. and H. van den Berg. 2003. How large is international trade's Effect on Economic Growth, Journal of Economic Surveys 17(3), 363-396.

Madsen, J.B. 1999. On Errors in Variable Biases in Estimates of Export Price Elasticities. Economics Letters, Vol. 63, No. 3, pp. 313-319.

Mody, A. and K. Yilmaz. 1997. Is There Persistence in the Growth of Manufactured Exports? Evidence from Newly Industrializing Countries, Journal of Development Economics, Vol. 53, No. 2, pp. 447-470.

Muscatelli, V.A. 1995. NIE Export Performance Revisited: The Estimation of Export Demand Elasticities, and the Role of Product Differentiation and Growth, in: D. Vines and D. Currie (Eds.), North-South linkages and international macroeconomic policy (pp. 9-28), Cambridge, New York and Melbourne: Cambridge University Press.

Prebisch, R. 1950. The Economic Development of Latin America and its Principal Problems, Economic Bulletin for Latin America, Vol. VII, No. 1, February 1962 (reprinted), pp.1-22.

, 1959. Commercial Policy in the Underdeveloped Countries, The American Economic Review, Vol. XL IX/2, May, pp. 251-273.

Reinhart, C. 1995. Devaluation, Relative Prices, and International Trade, International Monetary Fund Staff Papers, Vol. 42, No. 2, pp. 290-312.

Riedel, J. and P. Athukorala. 1995. Export Growth and the Terms of Trade: The Case of the Curious Elasticities, in D. Vines and D. Currie (Eds.), North-South linkages and international macroeconomic policy (pp. 29-45), Cambridge, New York and Melbourne: Cambridge University Press.

Riezman, R.G., C.H. Whiteman and P.M. Summers. 1996. The Engine of Growth or its Handmaiden? Empirical Economics, 21, pp. 77-110.

Senhadji, A. and C. Montenegro. 1998. Time Series Analysis of Export Demand Equations: A Cross-Country Analysis, International Monetary Fund Working Papers, WP/98/149. 
Solow, R.M. 1956. A Contribution to the Theory of Economic Growth, Quarterly Journal of Economics, LXX, 1, February 1956, pp. 65-94.

Verspagen, B. 1993. Uneven Growth between Interdependent Economies, Avebury, Aldershot.

Verspagen, B. (1995). R\&D and Productivity: A Broad Cross-Section Cross-Country

Look, Journal of Productivity Analysis, July 1995, v. 6, iss. 2, pp. 117-35.

Wacziarg, R. 2001. Measuring the dynamic gains from Trade, World Bank Economic Review 15, 393-429.

Ziesemer, T. 1995. Economic Development and Endogenous Terms-of-Trade Determination: Review and Reinterpretation of the Prebisch-Singer Thesis, UNCTAD Review 1995, pp. 17-33. 
Table 1: Regression results for the system of equations

\begin{tabular}{|c|c|c|c|c|}
\hline & Method & GMM (a) & GMM (d) & GMM (e) \\
\hline Variable & Coefficient & Coeff/(t-val) & Coeff/(t-val) & Coeff/(t-val) \\
\hline \multirow[t]{2}{*}{ constants } & & $19.23 / 7.23$ & $15.19 / 2.73$ & $15.18 / 3.73$ \\
\hline & & $10.51 / 3.16$ & $8.76 / 3.21$ & $5.24 / 3.2$ \\
\hline \multirow[t]{2}{*}{ Ins } & $c(2)=(\eta+1) / \eta$ & 0.46 & 0.80 & 0.7385 \\
\hline & & (12.59) & $(25.04)$ & (23.33) \\
\hline \multirow[t]{2}{*}{$\mathrm{t}$} & $c(3)=b^{*}(\eta+1) / \eta$ & 0.01 & 0.01 & 0.0025 \\
\hline & & (2.89) & $(2.24)$ & $(.53)$ \\
\hline \multirow[t]{2}{*}{$\operatorname{lnK}(-1)$} & $c(4)=(\beta \eta+\beta-\eta) / \eta$ & -0.85 & -0.72 & -0.7888 \\
\hline & & $-(7.60)$ & $-(7.04)$ & $-(5.03)$ \\
\hline \multirow[t]{2}{*}{$\operatorname{lnL}$} & $c(5)=\alpha(\eta+1) / \eta$ & 0.23 & 0.36 & 0.5228 \\
\hline & & $(1.56)$ & (1.87) & $(1.88)$ \\
\hline \multirow[t]{2}{*}{$d \ln Z^{*} t$} & $c(6)=-\rho / \eta$ & 0.10 & 0.07 & 0.0658 \\
\hline & & $(4.32)$ & (5.63) & $(3.24)$ \\
\hline \multirow[t]{2}{*}{ Inkhatplusd(-1) } & & - & 0.25 & 0.1339 \\
\hline & & & $(7.16)$ & $(2.57)$ \\
\hline \multirow[t]{2}{*}{$\ln p(-1)$} & & - & 0.73 & 0.6886 \\
\hline & & & $(13.46)$ & (13.09) \\
\hline \multirow[t]{2}{*}{ lagged residual } & & & & 0.7174 \\
\hline & & & & $(3.08)$ \\
\hline \multicolumn{5}{|c|}{ Identified parameters } \\
\hline \multicolumn{2}{|l|}{ prod.elas.labour $\alpha$} & 0.492 & 0.456 & 0.71 \\
\hline \multicolumn{2}{|l|}{$\begin{array}{l}\text { prod.elas.capital } \beta \\
\text { tot.faact.prod. }\end{array}$} & 0.316 & 0.353 & 0.29 \\
\hline \multicolumn{2}{|l|}{ gr.b } & 0.021 & 0.0096 & 0.00345 \\
\hline \multicolumn{2}{|l|}{ exp. inc.elas. $\rho$} & 0.193 & 0.328 & 0.25 \\
\hline \multicolumn{2}{|l|}{ exp.priceelas. $\eta$} & -1.86 & -4.94 & -3.82 \\
\hline \multicolumn{2}{|l|}{ intial prod.level A } & $1.63 \times 10 \exp (5)$ & $2.6 \times 10 \exp 5$ & 93504 \\
\hline \multicolumn{2}{|l|}{ exp.level param. B } & $1.14 \times 10 \mathrm{e} 11$ & $1.83 \times 10 \mathrm{e} 11$ & $1.48 \times 10 \mathrm{e} 11$ \\
\hline \multicolumn{2}{|l|}{ adj.R-sq } & $0.88 / .74$ & $0.96 / .87$ & $.96 / .87$ \\
\hline \multicolumn{2}{|l|}{ No.obs } & $22 / 24$ & $22 / 24$ & $17 / 24$ \\
\hline \multicolumn{2}{|l|}{$\mathrm{J}$ statistic } & 0.32 & 0.459 & 0.449 \\
\hline \multicolumn{2}{|l|}{$\mathrm{nJ}<\mathrm{c}$ (d.f.) (b) } & $22 x .32<18.31(10)$ & $22 x .46<18.31(10)$ & $17 \times .45<19.68(11)$ \\
\hline \multicolumn{2}{|l|}{$\mathrm{nJ}<\mathrm{c}($ d.f. $)(\mathrm{c})$} & $24 \times .32<9.49(4)$ & $24 x .46<14.07(7)$ & $24 \times .45<14.07(7)$ \\
\hline \multicolumn{2}{|l|}{ Durbin-Watson } & $1.06 / .88$ & $1.52 / 2.25$ & $2.04 / 2.24$ \\
\hline
\end{tabular}

(a) Instruments:regressors, plus Ink(-2) to (-7) in the first equation and none in the second.

(b) for the first equation at the $5 \%$; degrees of freedom is number of constraints, which is 4 , plus number of lagged instruments.

(c) for the second equation at the $5 \%$;degrees of freedom is number of constraints, which is 4 , plus number of lagged instruments.

(d) Instruments: regressors plus dlnk(-1) to $(-5)$ and two lags of the dependent variable in the first equation and $\operatorname{lnp}(-2)$ to $(-4)$ in the second.

(e) Instruments as in previous regression plus lagged residual regressor 
Table 2: $\quad$ Overview of income and price elasticities of export demand for Brazil

\begin{tabular}{|l|l|l|c|c|c|c|}
\hline \multicolumn{1}{|c|}{ Year } & \multicolumn{1}{|c|}{ Author } & \multicolumn{1}{c|}{ Period } & $\mathbf{y}$ & $\mathbf{p m} / \mathbf{p d}$ & $\mathbf{p m}$ & $\mathbf{p d}$ \\
\hline 1969 & $\begin{array}{l}\text { Houthakker, } \\
\text { Magee }\end{array}$ & $1951-1966$ & 0,34 & $-0,39$ & & \\
\hline 1976 & Lemgruber & $1965-1974$ & $1,97^{*}$ & $-0,41^{*}$ & & \\
\hline 1984 & Aggarwal & $1969-1978$ & $0,253^{*}$ & $-1,23^{*}$ & & \\
\hline 1986 & $\begin{array}{l}\text { Bahmani- } \\
\text { Oskooee }\end{array}$ & $\begin{array}{l}1974: 1- \\
1980: 4\end{array}$ & 0,007 & $-0,151$ & & \\
\hline 1988 & Zini & $\begin{array}{l}1970: 1- \\
1986: 3\end{array}$ & $0,690^{*}$ & & $-0,171^{*}$ & 0,131 \\
\hline 1992 & $\begin{array}{l}1967-1983 \\
\end{array}$ & $\begin{array}{l}\text { Faini, } \\
\text { Critchett, }\end{array}$ & $0,60^{*}$ & $-1,51^{*}$ & & \\
\hline 1993 & Bavijo & & & & \\
\hline 1995 & Reinhart & $1964-1985$ & 3,93 & & & \\
\hline
\end{tabular}

y: foreign market income

pm: import unit value index

pd: domestic producer price or wholesale index

*: significance at 5\% level

Source: Bairam (1988), Fullerton et al. 1999, Houthakker and Magee (1969), Reinhart (1995). 


\begin{tabular}{|c|c|c|c|c|c|}
\hline$d \ln L$ & 0.02850 & 0.02000 & 0.01000 & 0.00500 & 0.00100 \\
\hline dlnk & -0.00420 & -0.00134 & 0.00200 & 0.00374 & 0.00510 \\
\hline dlnp & -0.00630 & -0.00430 & -0.00194 & -0.00077 & 0.00017 \\
\hline dlny & -0.00210 & 0.00295 & 0.00396 & 0.00448 & 0.00489 \\
\hline g & 0.02387 & 0.02387 & 0.02387 & 0.02387 & 0.02387 \\
\hline $\mathrm{m}$ & 1.27000 & 1.27000 & 1.27000 & 1.27000 & 1.27000 \\
\hline s & -0.00770 & -0.00770 & -0.00770 & -0.00770 & -0.00770 \\
\hline$x$ & 0.00460 & 0.00466 & 0.00475 & 0.00479 & 0.00480 \\
\hline $\mathrm{t}$ & -0.00250 & -0.00172 & -0.00077 & -0.00031 & 0.00007 \\
\hline$g^{*}(d \ln Z$ & -0.00006 & 0.00014 & 0.00038 & 0.00050 & 0.00060 \\
\hline$m^{*} b$ & 0.00438 & 0.00438 & 0.00438 & 0.00438 & 0.00438 \\
\hline$s^{*} d \ln L$ & -0.00022 & -0.00015 & -0.00008 & -0.00004 & -0.00001 \\
\hline
\end{tabular}


Figure 1: The Relationship between the Growth Rate of per capita incomeand the Income Elasticity of Exports (for various Values of the Price Elasticity)

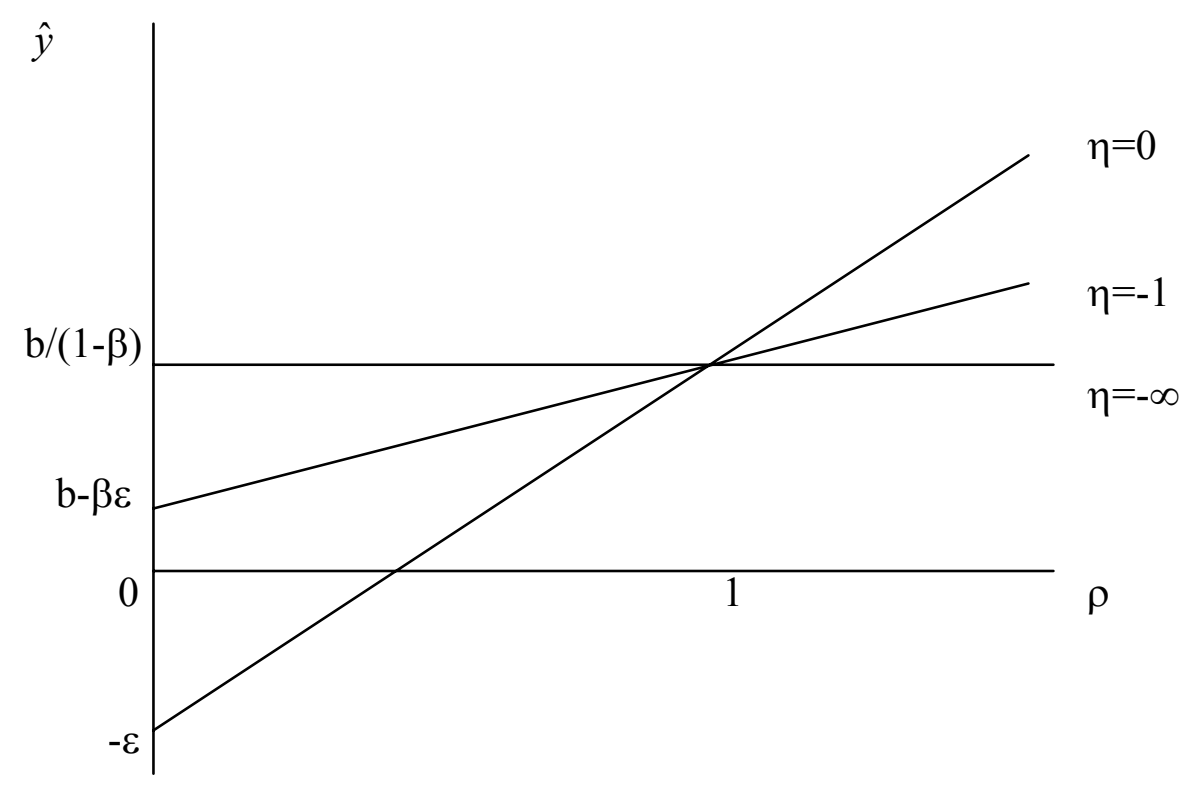


Figure 2: The Relationship between the Growth Rate of the Terms of Trade and the Income Elasticity of Export Demand (for various Values of the Price Elasticity)

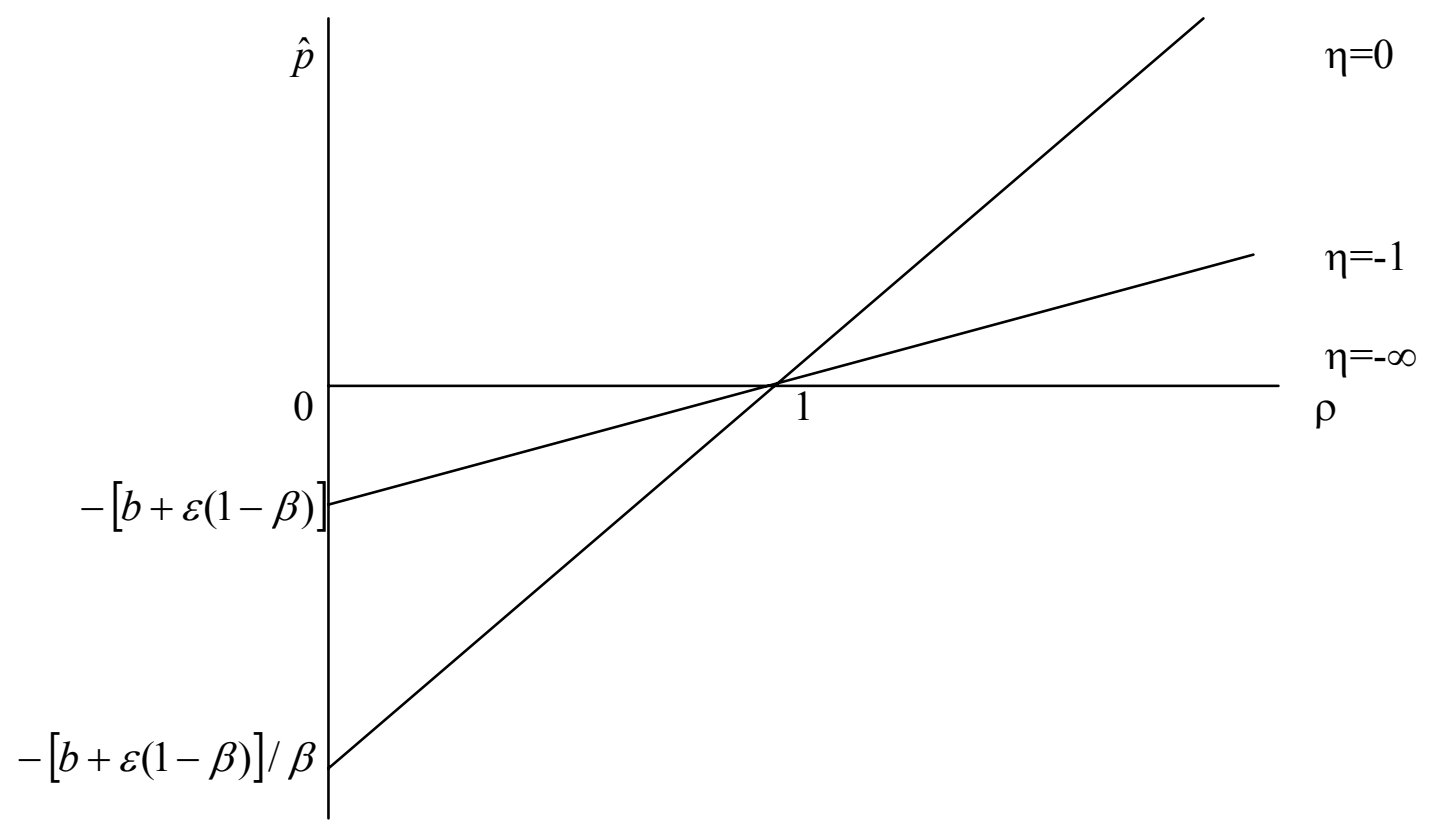


Figure 4: Plot of employment (in natural logs) and its growth rate
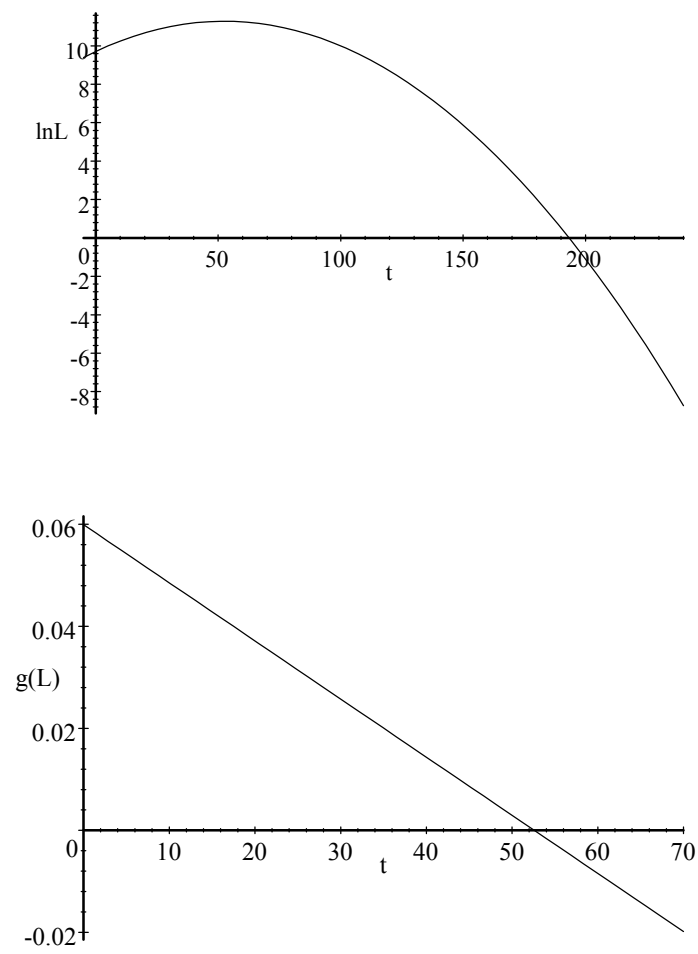


\section{Appendix: Data (not for publication)}

$\begin{array}{ll}\text { Brazil InkhatplusdeltalnK } & \mathrm{t} \\ 1960 & 1 \\ 1961 & 2 \\ 1962 & 3 \\ 1963 & 4 \\ 1964 & 5 \\ 1965 & 6 \\ 1966 & 6 \\ 1967 & 8 \\ 1968 & 8\end{array}$

1969

$$
1970
$$

$$
1971
$$

1972

1973

1974

1975

1976

1977

1978

1979

1980

1981

1982

1983

1984

1985

1986

1987

1988

1989

1990

1991

1992

1993

1994

1995

1996

1997

1998

1999

2000

2001

2002

\section{$-2.02261$}

$-1.96591$

$-1.93139$

$-1.8573$

$-1.83147$

$-1.83757$

$-1.93903$

$-2.04525$

$-2.06595$

$-2.05635$

$-2.06323$

$-2.18973$

$-2.32046$

$-2.57474$

$-2.63203$

$-2.58808$

$-2.43519$

$-2.30033$

$-2.34436$

$-2.28746$

$-2.56655$

$-2.72118$

$-2.73742$

$-2.6732$

$-2.57727$

$-2.58478$

$-2.66644$

$-2.64737$

$-2.67397$

$-2.71031$

$-2.58009$

$-2.66117$

$-2.73956$
26.4789610

26.5742711

$26.6773 \quad 12$

26.7852513

26.9043414

27.0275215

27.1497216

27.2565617

27.3489118

27.4386119

27.5295320

27.6195721

27.6945222

27.7557523

27.7949224

27.8298525

27.8680226

$27.9186 \quad 27$

27.9818228

28.0407329

28.1052630

28.1450631

28.1738532

28.2015933

28.2336234

$28.2726 \quad 35$

28.3110236

28.3435237

28.3773538

28.4093339

28.4388540

28.4776141

28.5104842

28.5380843 $\ln L$

$\begin{array}{lll}\ln Z & \ln p & \text { LNS } \\ 29.69953 & 0.679 & \text { \#VALUE }\end{array}$

29.746950 .592863 \#VALUE!

29.799470 .3723 \#VALUE!

$29.8486 \quad 0.386142$ \#VALUE!

$29.9136 \quad 0.523813$ \#VALUE!

29.962580 .547637 \#VALUE!

30.019050 .511925 \#VALUE!

30.064990 .486691 \#VALUE!

$30.1248 \quad 0.451679$ \#VALUE!

30.184360 .489117 \#VALUE!

$30.230370 .575362-1.617302$

$30.271360 .560735-1.569271$

$10.39754330 .326050 .567483-1.543731$

$10.47356330 .388310 .678765-1.488357$

\#NUM! $\quad 30.402050 .495395-1.426318$

\#NUM! $\quad 30.4104 \quad 0.466377-1.356523$

$10.54634130 .458280 .586685-1.434932$

$10.6011 \quad 30.496250 .716926-1.482443$

$10.6349930 .537870 .561119-1.439907$

$10.66211830 .578460 .461907-1.403873$

\#NUM! $\quad 30.597320 .29566 \quad-1.40719$

$10.72469830 .614480 .15327-1.395637$

$10.77741330 .618620 .143164-1.457585$

$10.78861830 .6445 \quad 0.138787-1.616392$

$10.82395 \quad 30.688930 .20937-1.688631$

$10.89230430 .7227 \quad 0.151116-1.688791$

$10.92298430 .755370 .296645-1.573031$

$10.95797430 .791290 .187074-1.416217$

$10.98068930 .836690 .277637-1.392028$

$11.01241330 .874160 .156823-1.303492$

$11.03650130 .90294-0.02475-1.473271$

\#NUM! $\quad 30.91879-0.06418-1.602079$

$11.08820130 .93699-0.12474-1.58101$

$11.10600930 .95115-0.0479-1.53771$

\#NUM! $\quad 30.98128-0.08493-1.467335$

$11.15093631 .009050 \quad-1.477455$

$11.12608631 .04075-0.00191-1.548237$

$11.14666231 .074860 .011468-1.528652$

$11.15572231 .09632-0.03549-1.519318$

$11.17991131 .12501-0.12514-1.529679$

\#NUM! $\quad 31.16374-0.10866-1.411217$

$11.23133131 .17652-0.14293-1.466674$

\#NUM! $\quad 31.19536-0.13813-1.526736$ 


\section{Appendix: GMM regressions (not for publication)}

\section{First regression in Table 1}

System: SYS12

Estimation Method: Generalized Method of Moments

Date: 01/12/05 Time: 15:15

Sample: 19722001

Included observations: 24

Total system (unbalanced) observations 46

Estimation settings: tol $=0.00010$, derivs=analytic

Initial Values: $\mathrm{C}(1)=18.8587, \mathrm{C}(2)=0.47086, \mathrm{C}(3)=0.00970, \mathrm{C}(4)=$

$-0.81866, C(5)=0.17414, C(6)=0.09331, C(7)=7.42517$

Kernel: Bartlett, Bandwidth: Andrews (3.94), No prewhitening

Iterate coefficients after one-step weighting matrix

Convergence achieved after: 1 weight matrix, 10 total coef iterations

$\begin{array}{lllll} & \text { Coefficient } & \text { Std. Error } & \text { t-Statistic } & \text { Prob. } \\ \text { C(1) } & & & & \\ \mathrm{C}(2) & 19.22756 & 1.830304 & 10.50512 & 0.0000 \\ \mathrm{C}(3) & 0.462891 & 0.036780 & 12.58534 & 0.0000 \\ \mathrm{C}(4) & 0.009824 & 0.003400 & 2.889392 & 0.0063 \\ \mathrm{C}(5) & -0.853572 & 0.112293 & -7.601293 & 0.0000 \\ \mathrm{C}(6) & 0.227595 & 0.145824 & 1.560749 & 0.1267 \\ \mathrm{C}(7) & 0.103396 & 0.023916 & 4.323295 & 0.0001 \\ & 7.228569 & 2.288196 & 3.159069 & 0.0031 \\ \text { Determinant residual covariance } & & & \\ \text { J-statistic } & & & \\ \end{array}$

Equation: LNKHATPLUSD $=\mathrm{C}(1)+\mathrm{C}(2)^{*} \mathrm{LNS}+\mathrm{C}(3)^{*} \mathrm{~T}+\mathrm{C}(4)^{*} \mathrm{LNK}(-1)$ $+\mathrm{C}(5)^{\star} \mathrm{LNL}+\mathrm{C}(6)^{\star} \mathrm{D}(\mathrm{LNZ})^{\star} \mathrm{T}$

Instruments: C LNS T LNK(-1) LNL D(LNZ)*T LNK(-2) LNK(-3) LNK(-4) LNK(-5) LNK(-6) LNK(-7)

Observations: 22

$\begin{array}{llll}\text { Adjusted R-squared } & 0.882874 & \text { S.D. dependent var } & 0.253595 \\ \text { S.E. of regression } & 0.086790 & \text { Sum squared resid } & 0.120519\end{array}$

Durbin-Watson stat 1.063375

Equation: $\mathrm{LNP}=\mathrm{C}(7)+(\mathrm{C}(2)-1)^{*} \mathrm{LNS}+\left((\mathrm{C}(2)-1)^{*} \mathrm{C}(3) / \mathrm{C}(2)\right)^{*} \mathrm{~T}+((\mathrm{C}(2)-1)$

$\left.{ }^{*} \mathrm{C}(5) / \mathrm{C}(2)\right)^{\star} \mathrm{LNL}+(\mathrm{C}(2)-1)^{*}((\mathrm{C}(4)+1) / \mathrm{C}(2))^{*} \mathrm{LNK}(-1)+\mathrm{C}(6)^{*} \mathrm{D}(\mathrm{LNZ})^{*} \mathrm{~T}$

Instruments: C LNS T LNK(-1) LNL D(LNZ)*T

Observations: 24

$\begin{array}{llll}\text { R-squared } & 0.795699 & \text { Mean dependent var } & 0.199807 \\ \text { Adjusted R-squared } & 0.738949 & \text { S.D. dependent var } & 0.265522 \\ \text { S.E. of regression } & 0.135664 & \text { Sum squared resid } & 0.331283\end{array}$




\section{Second regression in Table 1}

System: SYS12

Estimation Method: Generalized Method of Moments

Date: 01/12/05 Time: 16:42

Sample: 19722001

Included observations: 24

Total system (unbalanced) observations 46

Estimation settings: tol $=0.00010$, derivs $=$ analytic

Initial Values: $\mathrm{C}(1)=15.7413, \mathrm{C}(2)=0.73475, \mathrm{C}(3)=0.00753, \mathrm{C}(4)=$

$-0.54434, C(5)=-0.16702, C(6)=0.07191, C(8)=0.45229$,

$C(7)=3.58979, C(9)=0.70147$

Kernel: Bartlett, Bandwidth: Andrews (1.92), No prewhitening

Iterate coefficients after one-step weighting matrix

Convergence achieved after: 1 weight matrix, 15 total coef iterations

$$
\text { Coefficient Std. Error t-Statistic Prob. }
$$

\begin{tabular}{|c|c|c|c|c|}
\hline$C(1)$ & 15.19385 & 1.734346 & 8.760562 & 0.0000 \\
\hline$C(2)$ & 0.797500 & 0.031855 & 25.03566 & 0.0000 \\
\hline$C(3)$ & 0.007677 & 0.003429 & 2.239206 & 0.0312 \\
\hline $\mathrm{C}(4)$ & -0.718863 & 0.102134 & -7.038409 & 0.0000 \\
\hline$C(5)$ & 0.362634 & 0.194307 & 1.866298 & 0.0699 \\
\hline$C(6)$ & 0.066517 & 0.011804 & 5.634965 & 0.0000 \\
\hline $\mathrm{C}(8)$ & 0.253702 & 0.035419 & 7.162980 & 0.0000 \\
\hline$C(7)$ & 2.726818 & 0.849442 & 3.210129 & 0.0027 \\
\hline $\mathrm{C}(9)$ & 0.727829 & 0.054080 & 13.45844 & 0.0000 \\
\hline \multicolumn{3}{|c|}{ residual covariance } & \multicolumn{2}{|l|}{$\begin{array}{l}1.03 E-05 \\
0458764\end{array}$} \\
\hline
\end{tabular}

Equation: LNKHATPLUSD $=\mathrm{C}(1)+\mathrm{C}(2)^{*} \mathrm{LNS}+\mathrm{C}(3)^{*} \mathrm{~T}+\mathrm{C}(4)^{*} \mathrm{LNK}(-1)$ $+\mathrm{C}(5)^{*} \mathrm{LNL}+\mathrm{C}(6)^{*} \mathrm{D}(\mathrm{LNZ})^{*} \mathrm{~T}+\mathrm{C}(8)^{*} \mathrm{LNKHATPLUSD}(-1)$

Instruments: C LNS T LNK(-1) LNL D(LNZ)*T LNK(-2) LNK(-3) LNK(-4) LNK(-5) LNKHATPLUSD(-1) LNKHATPLUSD(-2)

Observations: 22

$\begin{array}{llll}\text { R-squared } & 0.972347 & \text { Mean dependent var } & -2.440917\end{array}$

$\begin{array}{llll}\text { Adjusted R-squared } & 0.961286 & \text { S.D. dependent var } & 0.253595\end{array}$

S.E. of regression $\quad 0.049897 \quad$ Sum squared resid $\quad 0.037346$

Durbin-Watson stat 1.522321

Equation: $\mathrm{LNP}=\mathrm{C}(7)+(\mathrm{C}(2)-1)^{*} \mathrm{LNS}+\left((\mathrm{C}(2)-1)^{*} \mathrm{C}(3) / \mathrm{C}(2)\right)^{*} \mathrm{~T}+((\mathrm{C}(2)-1)$ $\left.{ }^{*} \mathrm{C}(5) / \mathrm{C}(2)\right)^{*} \mathrm{LNL}+(\mathrm{C}(2)-1)^{*}((\mathrm{C}(4)+1) / \mathrm{C}(2))^{*} \mathrm{LNK}(-1)+\mathrm{C}(6)^{*} \mathrm{D}(\mathrm{LNZ})^{*} \mathrm{~T}$ $+\mathrm{C}(9)^{*} \mathrm{LNP}(-1)$

Instruments: C LNS T LNK(-1) LNL D(LNZ)*T LNP(-1) LNP(-2) LNP(-3) $\operatorname{LNP}(-4)$

Observations: 24

$\begin{array}{llll}\text { R-squared } & 0.905212 & \text { Mean dependent var } & 0.199807 \\ \text { Adjusted R-squared } & 0.871757 & \text { S.D. dependent var } & 0.265522 \\ \text { S.E. of regression } & 0.095086 & \text { Sum squared resid } & 0.153704\end{array}$

Durbin-Watson stat $\quad 2.250973$ 


\section{Third regression in Table 1}

\section{System: SYS12}

Estimation Method: Generalized Method of Moments

Date: 01/14/05 Time: 12:32

Sample: 19722001

Included observations: 24

Total system (unbalanced) observations 41

Estimation settings: tol $=0.00010$, derivs $=$ analytic

Initial Values: $C(1)=15.4047, C(2)=0.73729, C(3)=0.00299, C(4)=$ $-0.79557, C(5)=0.51780, C(6)=0.06542, C(8)=0.13214$, $C(10)=0.75654, C(7)=3.67535, C(9)=0.68820$

Kernel: Bartlett, Bandwidth: Andrews (0.53), No prewhitening

Iterate coefficients after one-step weighting matrix

Convergence achieved after: 1 weight matrix, 13 total coef iterations

$\begin{array}{lllll} & \text { Coefficient } & \text { Std. Error } & \text { t-Statistic } & \text { Prob. } \\ \text { C(1) } & & & & \\ \mathrm{C}(2) & 15.17896 & 2.894769 & 5.243583 & 0.0000 \\ \mathrm{C}(3) & 0.738511 & 0.031650 & 23.33386 & 0.0000 \\ \mathrm{C}(4) & 0.002548 & 0.004835 & 0.526937 & 0.6020 \\ \mathrm{C}(5) & -0.788770 & 0.156757 & -5.031788 & 0.0000 \\ \mathrm{C}(6) & 0.522816 & 0.277918 & 1.881189 & 0.0694 \\ \mathrm{C}(8) & 0.065827 & 0.020346 & 3.235290 & 0.0029 \\ \mathrm{C}(10) & 0.133912 & 0.052101 & 2.570252 & 0.0152 \\ \mathrm{C}(7) & 0.717384 & 0.232617 & 3.083970 & 0.0043 \\ \mathrm{C}(9) & 3.733201 & 1.166555 & 3.200193 & 0.0032 \\ & 0.688591 & 0.052622 & 13.08568 & 0.0000 \\ \text { Determinant residual covariance } & & & \\ \text { J-statistic } & & & & \\ \end{array}$

Equation: LNKHATPLUSD $=\mathrm{C}(1)+\mathrm{C}(2)^{*} \mathrm{LNS}+\mathrm{C}(3)^{*} \mathrm{~T}+\mathrm{C}(4)^{*} \mathrm{LNK}(-1)$ $+\mathrm{C}(5)^{*} \mathrm{LNL}+\mathrm{C}(6)^{*} \mathrm{D}(\mathrm{LNZ})^{*} \mathrm{~T}+\mathrm{C}(8)^{*} \mathrm{LNKHATPLUSD}(-1)+\mathrm{C}(10)$ ${ }^{*}$ RESID49(-1)

Instruments: C LNS T LNK(-1) LNL D(LNZ)*T LNK(-2) LNK(-3) LNK(-4) LNK(-5) LNKHATPLUSD(-1) LNKHATPLUSD(-2) RESID49(-1)

Observations: 17

$\begin{array}{llll}\text { R-squared } & 0.962889 & \text { Mean dependent var } & -2.446356 \\ \text { Adjusted R-squared } & 0.934025 & \text { S.D. dependent var } & 0.234242 \\ \text { S.E. of regression } & 0.060166 & \text { Sum squared resid } & 0.032580\end{array}$

Equation: LNP $=\mathrm{C}(7)+(\mathrm{C}(2)-1)^{*} \mathrm{LNS}+\left((\mathrm{C}(2)-1)^{*} \mathrm{C}(3) / \mathrm{C}(2)\right)^{*} \mathrm{~T}+((\mathrm{C}(2)-1)$ $\left.{ }^{*} \mathrm{C}(5) / \mathrm{C}(2)\right)^{*} \mathrm{LNL}+(\mathrm{C}(2)-1)^{*}((\mathrm{C}(4)+1) / \mathrm{C}(2))^{*} \mathrm{LNK}(-1)+\mathrm{C}(6)^{*} \mathrm{D}(\mathrm{LNZ})^{*} \mathrm{~T}$ $+\mathrm{C}(9)^{\star} \mathrm{LNP}(-1)$

Instruments: C LNS T LNK(-1) LNL D(LNZ)*T LNP(-1) LNP(-2) LNP(-3) $\operatorname{LNP}(-4)$

Observations: 24

R-squared $\quad 0.906524$

Adjusted R-squared $\quad 0.873533$

Mean dependent var $\quad 0.199807$

S.E. of regression $\quad 0.094426$

S.D. dependent var $\quad 0.265522$

Durbin-Watson stat 2.236543

Sum squared resid $\quad 0.151575$ 


\footnotetext{
${ }^{1}$ We want to thank Harry Bloch and Bart Verspagen for useful comments on an earlier draft and Abraham Garcia, Clemens Kool, Pierre Mohnen, Franz Palm, Jean-Pierre Urbain for useful talks. Responsibility is entirely ours.

${ }^{2}$ Two recent publications are Dritsakis (2004) and Dawson and Hubbard (2004). They provide evidence for Central and Eastern European countries and many recent references to this bulk of literature.

${ }^{3}$ A separate estimate of the export demand function in terms of growth rates yields a growth rate of B which is insignificantly different from zero.

${ }^{4}$ For Brazil, Gross fixed Capital formation (GFCF) is about twice as large as total imports. For 1995 (but not for other years) we can calculate from the WDI that production of machinery and transport equipment is about \$US 38.1 billion. This is about $25 \%$ of GFCF. However, of these \$US38mln, 8.8 are exported, leaving about 29 for domestic investment. On the other hand, 21 are imported according to the UN Intern. Trade Statistics Yearbook, indicating that about $42 \%$ of machinery and transport equipment is imported provided it is not re-exported. Unfortunately it seems impossible to construct separate stocks of domestic and foreign capital without having similar information for other items and periods of GFCF than just machinery and transport as of 1995.

${ }^{5}$ See Verspagen (1995) for an extensive explanation.

${ }^{6}$ Below we will also employ the Breusch-Godfrey test because of the endogeneity problem discussed earlier, because the DW statistic is not the adequate tool in case of endogeneity.

${ }^{7}$ The idea comes from the standard Breusch-Godfrey test where the lagged residuals are added to the regression equation (see Davidson and MacKinnon 2004). We are aware of the fact that our procedure to use it as a correction for autocorrelation is only loosely related and that our approach may evoke a discussion. The only alternative we have is to focus on the other regressions with serial correlation.
} 